\title{
UPAYA MELEPAS BUDAYA KORUPSI YANG TELAH MENGAKAR DI PARTAI POLITIK REPUBLIK INDONESIA
}

\author{
Guntarto Widodo, Nur Sa'adah \\ Fakultas Hukum Universitas Pamulang \\ guntartowidodo@gmail.com
}

\begin{abstract}
Corruption is considered as a moral disease, and there is even a tendency to develop more and more with multifactorial causes. This research is a type of descriptive research that has normative juridical nature, namely a research aimed at finding and formulating legal arguments in the analysis of the main problems. Corruption itself is an activity carried out to enrich oneself or a group where the activity violates the law because it has harmed the nation and state. Efforts to remove the culture of corruption that has taken root in the existing Political Parties in the Republic of Indonesia are strategies through preventive, detective and repressive aspects, which are carried out intensively and continuously. The legal consequence of corruption committed by the Commissioner and the former PDIP candidate is receiving a heavy punishment.
\end{abstract}

Keywords: Corruption, Culture, Efforts

\begin{abstract}
ABSTRAK
Korupsi sudah dianggap sebagai penyakit moral, bahkan ada kecenderungan semakin berkembang dengan penyebab multifaktor. Penelitian ini termasuk jenis penelitian deskriptif yang bersifat yuridis normatif yaitu penelitian yang ditujukan untuk menemukan dan merumuskan argumentasi hukum dalam analisis terhadap pokok permasalahan. Tindak Pidana Korupsi sendiri adalah kegiatan yang dilakukan untuk memperkaya diri sendiri atau kelompok dimana kegiatan tersebut melanggar hukum karena telah merugikan bangsa dan negara. Upaya melepas budaya korupsi yang telah mengakar di Partai Politik yang ada di Republik Indonesia adalah dengan strategi melalui aspek preventif, detektif dan represif, yang dilaksanakan secara intensif dan terus menerus. Akibat hukum terhadap tindak pidana korupsi yang dilakukan oleh pihak Komesioner dan pihak mantan caleg PDIP adalah menerima sanksi yang berat.
\end{abstract}

Kata Kunci : Korupsi, Budaya, Upaya 


\section{PENDAHULUAN}

Kata Korupsi sepertinya bagi kita tidak asing lagi, berita korupsi baik di media surat kabar maupun media elektronik . Persoalan korupsi seolah-olah menjelma sebagai budaya di Indonesia. Korupsi telah menancap kuat pada sendisendi kehidupan Negara dan memungkinkan akan menjadi budaya baru dalam hidup bernegara. Korupsi sudah menjadi bagian dari budaya bangsa. Andi Hamzah, dalam kamus hukumnya mengartikan bahwa "korupsi sebagai suatu perbuatan buruk, busuk, bejat, suka disuap, perbuatan yang menghina atau mefitnah, menyimpang dari kesucian, tidak bermoral" (Andi Hamzah, 2005: 4).

Bahwa tindakan korupsi yang terjadi dalam level manapun merupakan hal yang dapat menghancurkan nilai-nilai etika serta norma sosial dan nilai agama, sehingga dapat menjadi perilaku yang mengkorupsi budaya, dan ketika secara bertahap atau sekaligus diterima oleh masyarakat sebagai sesuatu yang wajar, maka disitu telah terjadi korupsi budaya yang kemudian membentuk budaya korupsi.

Baru-baru ini di media lagi hangathangatnya pemberitaan tentang tindakan korupsi yang dilakukan oleh Komisioner KPU Wahyu Setiawan dan mantan caleg PDI Perjuangan Harun Masiku. Hasil penyidik, penuntut umum dipimpin oleh tiga pimpinan KPK, bahwa dalam bukti permulaan cukup bahwa telah terjadi tindak pidana korupsi. Jadi bukan pidana umum dengan kategori penipuan. KPK menetapkan Harun menjadi tersangka pada Kamis, 9 Januari 2020. Selain Harun, lembaga ini juga menetapkan Wahyu Setiawan; mantan anggota Badan Pengawas Pemilu (Bawaslu) Agustiani Tio Fridelina; dan salah seorang penyuap Wahyu, Saeful Bahri. Harun diduga menyuap Wahyu lewat Agustiani dan Saeful untuk memuluskan jalan calon anggota legislatif dari daerah Pemilihan I
Sumatera Selatan ini menjadi anggota DPR lewat mekanisme pergantian antar waktu. Kasus Wahyu Setiawan dan mantan caleg PDI Perjuangan menunjukkan bobroknya lembaga negara dan parpol, yang seharusnya menjadi contoh masyarakat sehingga masyarakat akan semangat dalam memilih wakil-wakil baik itu Presiden dan wakil Presiden maupun DPR RI, DPRD serta DPD untuk mengurus negara yang kita cintai yaitu Negara Republik Indonesia.

Kalau dilihat secara personal mereka orang yang berkecukupan, dari segi gaji seorang Wahyu Setiawan sudah cukup memadai apalagi seorang Harun Masiku yang kaya raya. Terus apa yang menyebabkan melakukan tindakan korupsi. Jabatan, kesempatan, keserahkaan, karakter pada umumnya seseorang melakukan tindakan hukum. dalam Undang-Undang No 7 Tahun 2017 Pasal 1 ayat (8) Tentang Pemilihan Umum mengatakan bahwa yang dimaksud dengan Komisi Pemilihan Umum yang selanjutnya disingkat KPU adalah lembaga Penyelenggara Pemilu yang bersifat nasional, tetap, dan mandiri dalam melaksanakan Pemilu. Dalam menyelenggarakan Pemilu, KPU bebas dari pengaruh pihak mana pun berkaitan dengan pelaksanaan tugas dan wewenangnya. Menurut Kamus Umum Bahasa Indonesia bahwa kata korupsi adalah perbuatan yang buruk (W.J.S.Poerwadarminta, 2007 : 616). Sedangkan menurut Undang-Undang No 19 Tahun 2019 bahwa yang dinamakan tindak pidana korupsi adalah Setiap orang yang dikategorikan melawan hukum, melakukan perbuatan memperkaya diri sendiri, menguntungkan diri sendiri atau orang lain atau suatu korporasi, menyalahgunakan kewenangan maupun kesempatan atau sarana yang ada padanya karena jabatan atau kedudukan yang dapat merugikan 
keuangan negara atau perekonomian negara.

Dari pengertian diatas bahwa ada peristiwa hukum yang dilakukan antara Wahyu Setiawan dengan mantan caleg PDI Perjuangan Harun Masiku, yang dinilai telah melakukan perbuatan melawan hukum, unsur-unsur dari Perbuatan Melawan Hukum dalam kasus tindak pidana korupsi dinilai sudah cukup, diantaranya yaitu menyalahgunakan kewenangan maupun kesempatan atau sarana yang ada padanya karena jabatan atau kedudukan, sehingga menguntungkan diri sendiri atau orang lain.

\section{PERMASALAHAN}

Dari uraian latar belakang masalah di atas, penulis tertarik mengangkat masalah yang diteliti dalam jurnal ini yaitu: Bagaimana upaya melepas budaya korupsi yang telah mengakar di Partai Politik yang ada di Republik Indonesia ? Bagaimana akibat hukum terhadap tindak pidana korupsi yang dilakukan oleh pihak Komesioner dan pihak mantan caleg PDIP ?

\section{METODE PENELITIAN}

Sesuai dengan tujuan penelitian, maka jenis penelitian yang digunakan adalah penelitian deskriptif yang bersifat yuridis normatif, yaitu penelitian yang ditujukan untuk menemukan dan merumuskan argumentasi hukum dalam analisis terhadap pokok permasalahan. Penelitian hukum normatif dapat diartikan sebagai penelitian yang digunakan untuk mengkaji kaidah dan asas hukum. Metode pengumpulan data yang digunakan dengan alat pengumpulan data berupa studi kepustakaan dan studi dokumen. Studi kepustakaan dilakukan dengan cara memperoleh bahan hukum sekunder yang berasal dari buku dan/atau referensi yang berkaitan dengan pokok masalah penelitian, sedangkan studi dokumen dipergunakan sebagai alat pengumpul data untuk memperoleh data dan informasi yang tergolong sebagai bahan hukum primer mengenai hukum tentang perjanjian yang dilakukan secara lisan.

\section{PEMBAHASAN \\ Tindak Pidana Korupsi}

Pengertian korupsi menurut masyarakat awam khususnya adalah suatu tindakan mengambil uang negara agar memperoleh keuntungan untuk diri sendiri. Pengertian korupsi sendiri yang juga dikutip dari kamus besar bahasa indonesia pengertian korupsi sebagai berikut : "penyelewengan atau penggelapan (uang negara atau perusahaan, dan sebagainya untuk keuntungan pribadi atau orang lain. Menurut Andi Hamzah bahwa: “ Arti kata harafiah dari kata korupsi adalah kebusukan, keburukan, kebejatan, ketidakjujuran, dapat disuap, tidak bermoral, penyimpangan dari kesucian, kata-kata yang menghina atau memfitnah" (Andi Hamzah, 1991 : 9). Lebih lanjut Andi Hamzah mengatakan bahwa: "Kata korupsi berasal dari bahasa Latin Corruptio yang kemudian muncul dalam Bahasa Inggris dan Prancis Corruption, serta dalam bahasa Belanda Korruptie" (Andi Hamzah, 1985 : 143).

Menurut Beveniste dalam Suyatno bahwa : "Korupsi didefenisikan dalam 4 jenis yaitu sebagai berikut: (Ermansyah Djaja, 2010 : 23).

1. Discretionery corupption, ialah korupsi yang dilakukan karena adanya kebebasan dalam menentukan kebijakan, sekalipun nampaknya bersifat sah, bukanlah praktik-praktik yang dapat diterima oleh para anggota organisasi. Contoh : Seorang pelayan perizinan Tenaga Kerja Asing, memberikan pelayanan yang lebih cepat kepada "calo", 
atau orang yang bersedia membayar lebih, ketimbang para pemohon yang biasa-biasa saja. Alasannya karena calo adalah orang yang bisa memberi pendapatan tambahan.

2. Illegal corupption, ialah suatu jenis tindakan yang bermaksud mengacaukan bahasa atau maksud-maksud hukum, peraturan dan regulasi hukum.Contoh: di dalam peraturan lelang dinyatakan bahwa untuk pengadaan barang jenis tertentu harus melalui proses pelelangan atau tender. Tetapi karena waktunya mendesak (karena turunnya anggaran terlambat), maka proses itu tidak dimungkinkan. Untuk pemimpin proyek mencari dasar hukum mana yang bisa mendukung atau memperkuat pelaksanaan sehingga tidak disalahkan oleh inspektur. Dicarilah pasal-pasal dalam peraturan yang memungkinkan untuk bisa digunakan sebagai dasar hukum guna memperkuat sahnya pelaksanaan tender. Dalam pelaksanaan proyek seperti kasus ini, sebenarnya sah atau tidak sah, bergantung pada bagaimana para pihak menafsirkan peraturan yang berlaku. Bahkan dalam beberapa kasus, letak illegal corruption berada pada kecanggihan memainkan kata-kata; bukan substansinya.

3. Mercenery corruption, ialah jenis tindak pidana korupsi yang dimaksud untuk memperoleh keuntungan pribadi, melalui penyalahgunaan wewenang dan kekuasaan. Contoh: Dalam sebuah persaingan tender, seorang panitia lelang mempunyai kewenangan untuk meluluskan peserta tender. Untuk itu secara terselubung atau terang-terangan ia mengatakan untuk memenangkan tender peserta harus bersedia memberikan uang "sogok" atau "semir" dalam jumlah tertentu.

4. Ideologi corruption, ialah jenis korupsi ilegal maupun discretionery yang dimaksudkan untuk mengejar tujuan kelompok.Contoh: Kasus skandal watergate adalah contoh ideological corruption, dimana sejumlah individu memberikan komitmen mereka terhadap presiden Nixon ketimbang kepada undang-undang atau hukum. Penjualan aset-aset BUMN untuk mendukung pemenangan pemilihan umum.

Melihat dalam arti yang luas, korupsi adalah suatu tindakan yang dilakukan untuk memperkaya diri sendiri agar memperoleh suatu keuntungan baik pribadi maupun golongannya. Kegiatan memperkaya diri dengan menggunakan jabatan, dimana orang tersebut merupakan orang yang menjabat di departemen swasta maupun departeman pemerintahan. Korupsi sendiri dapat muncul dimana-mana dan tidak terbatas dalam hal ini saja, maka dari itu untuk mempelajari dan membuat solusinya kita harus dapat membedakan antara korupsi dan kriminalitas kejahatan.Menurut Muladi tindak pidana merupakan gangguan terhadap keseimbangan, keselarasan dan keserasian dalam kehidupan masyarakat yang mengakibatkan gangguan individual ataupun masyarakat (Muladi, $2002: 61$ ).

Seseorang dapat dipidanakan apabila dia telah terbukti melakukan tindak pidana. Adanya dasar kepatutan dipidananya perbuatan tersebut berkaitan dengan masalah sumber hukum untuk menyatakan suatu perbuatan sebagai tindak pidana atau bukan. 
Pengertian Tindak Pidana Korupsi sendiri adalah kegiatan yang dilakukan untuk memperkaya diri sendiri atau kelompok dimana kegiatan tersebut melanggar hukum karena telah merugikan bangsa dan negara. Dari sudut pandang hukum sebagaimana Undang-Undang No 20 Tahun 2001 Tentang Pemberantasan Tindak Pidana Korupsi, dalam kejahatan tindak pidana korupsi mencakup unsurunsur sebagai. berikut :

a. Penyalahgunaan kewenangan, kesempatan, dan sarana

b. Memperkaya diri sendiri, orang lain, atau korporasi

c. Merugikan keuangan negara atau perekonomian negara.

Contoh-contoh tindak pidana korupsi yang sering terjadi, dan ada juga beberapa perilaku atau tindakan korupsi lainnya:

a. Memberi atau menerima hadiah (Penyuapan)

b. Penggelapan dan pemerasan dalam jabatan

c. Ikut serta dalam penggelapan dana pengadaan barang

d. Menerima gratifikasi

\section{Budaya Korupsi} penyakit moral, bahkan ada kecenderungan semakin berkembang dengan penyebab multifaktor. Oleh karena itu penanganannya perlu dilakukan secara sungguh-sungguh dan sistematis, dengan menerapkan strategi yang komprehensif secara preventif, detektif, represif, simultan dan berkelanjutan dengan melibatkan semua unsur terkait, baik unsur-unsur Lembaga Tertinggi dan Tinggi Negara, maupun masyarakat luas.

Indonesia adalah negara yang beraneka ragam baik budaya, agama, bahasa dan sumber alam serta sejarah kerajaan-kerajaan. Bisa dikatakan bahwa Indonesia adalah negara yang kaya raya. Demikian juga dengan praktik korupsinya juga paling beraneka ragam. Praktik korupsi dimulai dari zaman penjajah sampai sekarang bahkan bertambah banyak yang melakukan tindak pidana korupsi. Apalagi dengan majunya ilmu pengetahuan dan teknologi yang terkadang sulit diberantas. Faktor-faktor yang merupakan seseorang atau korporasi melakukan korupsi sebagaimana disebutkan oleh Klitgaar Hamzah dalam bukunya Surachmin, Suhandi Cahaya menyatakan bahwa sebab-sebab terjadinya korupsi diantaranya adalah adanya deskresi pegawai yang terlalu besar, gaya hidup yang terlalu konsumtif, rendahnya akuntabilitas publik, Moral yang rendah serta lemahnya pengawasan ekstern (Surachmin, Suhandi Cahaya, 2011 : 106).

Beberapa teori yang menyebabkan terjadinya tindak pidana korupsi diantara

a. Teori korupsi menurut Robert Klitgaard bahwa korupsi terjadi karena adanya faktor kekuasaan dan monopoli yang tidak dibarengi dengan akuntabilitas.

b. Teori korupsi menurut Jack Bologne bahwa faktor-faktor penyebab korupsi adalah keserakahan (Greed), kesempatan (Opportunity), kebutuhan (needs) dan pengungkapan (expose). Keserakahaan berpotensi dimiliki setiap orang dan berkaitan dengan individu pelaku korupsi. Organisasi, Instansi atau masyarakat luas dalam keadaan tertentu membuka faktor kesempatan melakukan kecurangan. Faktor kebutuhan erat dengan individu-individu untuk menunjang hidupnya yang wajar. Dan faktor pengungkapan berkaitan dengan tindakan dan konsekuensi yang dihadapi oleh pelaku kecurangan apabila pelaku diketemukan melakukan kecurangan. 
c. Teori korupsi menurut Donald $\mathrm{R}$ Cressey bahwa tiga faktor yang berpengaruh terhadap fraud (kecurangan) adalah kesempatan, motivasi, rasionalisasi. Ketiga faktor tersebut memiliki derajat yang sama besar untuk saling berpengaruh.

d. Teori korupsi menurut Cost Benefit Model bahwa korupsi terjadi jika manfaat korupsi yang didapat/ dirasakan lebih besar dari biaya/resikonya (nilai manfaat bersih korupsi).

\section{Partai Politik}

Pengertian Partaimenurut Miriam Budiardjopartai adalah sekelompok orang yang seasas, sehaluan terutama di bidang politik (Mariam Budiarjo, 2011 : 27) Kata politik berasal dari bahasa Belanda politiek dan bahasa Inggris "Politics", yang masing-masing bersumber dari bahasa Yunani Politika yang berhubungan dengan negara dengan akar katanya Polites yaitu warga negara dan Polis yaitu Negarakota.Secara etimologi kata "politik" masih berhubungan dengan polisi, kebijakan.Kata "politis" berarti hal-hal yang berhubungan dengan politik.Kata "politisi" berarti orang-orang yang menekuni hal politik.

Partai politik adalah salah satu bentuk pengelompokan warga negara berdasarkan kesamaan pikiran dan kepentingan politik. Miriam Budiardjo mengatakan bahwa partai politik adalah salah satu kelompok yang terorganisir yang anggotanya mempunyai orientasi dan cita-cita yang sama. Tujuan kelompok ini adalah memperoleh kekuasaan politik dan merebut kedudukan politik dengan cara konstitusional untuk melaksanakan kebijakan-kebijakan mereka.

Undang-Undang No 2 Tahun 2011

Tentang Partai Politik Pasal 1 ayat (1) mengatakan bahwa partai politik adalah organisasi yang bersifat nasional dan dibentuk oleh sekelompok warga negara
Indonesia secara sukarela atas dasar kesamaan kehendak dan cita-cita untuk memperjuangkan dan membela kepentingan politik anggota, masyarakat, bangsa dan negara, serta memelihara keutuhan Negara Kesatuan Republik Indonesia berdasarkan Pancasila dan Undang-Undang Dasar Negara Republik Indonesia Tahun 1945. Tujuan dan fungsi partai politik sebagaimana tercantum dalam Undang-Undang Partai Politik adalah tujuan umum Partai Politik adalah mewujudkan cita-cita nasional bangsa Indonesia sebagaimana dimaksuddalam Pembukaan Undang-Undang Dasar Negara Republik IndonesiaTahun 1945, menjaga dan memelihara keutuhan Negara Kesatuan Republik Indonesia, mengembangkan kehidupan demokrasi berdasarkan Pancasila denganmenjunjung tinggi kedaulatan rakyat dalam Negara Kesatuan RepublikIndonesia, dan mewujudkan kesejahteraan bagi seluruh rakyat Indonesia.

Partai politik tidak hanya bertugas sebagai merebut kursi dan mengumpulkan suara pada saat pemilihan umum, tetapi partai politik juga berfungsi sebagai solusi untuk kepentingan bersama. Fungsi dari Partai Politik diantaranya berfungsi sebagai sarana pendidikan politik bagi anggota dan masyarakat luas agar menjadi warganegara Indonesia yang sadar akan hak dan kewajibannya dalam kehidupan bermasyarakat, berbangsa, dan bernegara, penciptaan iklim yang kondusif bagi persatuan dan kesatuan bangsa Indonesia untuk kesejahteraan masyarakat penyerap, penghimpun, dan penyalur aspirasi politik masyarakat dalam merumuskan dan menetapkan kebijakan negara, partisipasi politik warga negara Indonesia, rekrutmen politik dalam proses pengisian jabatan politik melalui mekanisme demokrasi dengan memperhatikan kesetaraan dan keadilan gender. 


\section{Komisi Pemilihan Umum}

Di masyarakat umumnya memberikan pengertian pemilu adalah sebagai sarana yang penting dalam kehidupan suatu negara yang menganut azas demokrasi yang memberi kesempatan berpartisipasi politik bagi warga negara untuk memilih wakilwakilnya yang akan menyuarakan dan menyalurkan aspirasi mereka. Pemilu adalah singkatan dari Pemilihan Lima Tahun yang digelar oleh rakyat Indonesia guna memilih anggota legislatif (DPR dan DPRD/DPD), baik tingkat kabupaten/kota dan propinsi sampai pusat. Sedangkan DPD adalah Dewan Pimpinan Daerah yang dipilih untuk mewakili daerah bukan partai politik

Menurut Morissan, bahwa "Pemilihan umum adalah cara atau sarana untuk mengetahui keinginan rakyat mengenai arah dan kebijakan negara kedepan. Paling tidak ada tiga macam tujuan pemilihan umum, yaitu memungkinkan peralihan pemerintahan secara aman dan tertib untuk melaksanakan kedaualatan rakyat dalam rangka melaksanakan hak asasi warga Negara” (Morissan, 2005 : 17).

Untuk memilih, Presiden dan Wakil Presiden anggota Dewan Perwakilan Rakyat, anggota Dewan Perwakilan Daerah, dan untuk memilih anggota Dewan Perwakilan Rakyat Daerah, yang dilaksanakan secara langsung, umum, bebas, rahasia, jujur, dan adil dalam Negara Kesatuan Republik Indonesia berdasarkan Pancasila dan Undang-Undang Dasar Negara Republik Indonesia Tahun 1945, maka dibentuklah lembaga penyelenggara pemilu. Di dalam Undang-Undang No 7 Tahun 2017 Pasal 1 ayat (8) Tentang Pemilihan Umum mengatakan bahwa yang dimaksud dengan Komisi Pemilihan Umum yang selanjutnya disingkat KPU adalah lembaga Penyelenggara Pemilu yang bersifat nasional, tetap, dan mandiri dalam melaksanakan Pemilu. Dalam menyelenggarakan Pemilu, KPU bebas dari pengaruh pihak mana pun berkaitan dengan pelaksanaan tugas dan wewenangnya

Dan di dalam Pasal 36 ayat (2) Undang-Undang No 7 Tahun 2017 Tentang Pemilihan Umum mengatakan bahwa KPU bersumpah di mana bunyi dari pada sumpah tersebut adalah "Demi Allah (Tuhan), saya bersumpah/berjanji: Bahwa saya akan memenuhi tugas dan kewajiban saya sebagai anggota komisi pemilihan umum. Komisi pemilihan umum Provinsi/Komisi pemilihan umum Kabupaten/Kota dengan sebaik-baiknya sesuai dengan peraturan perundang dengan berpedoman pada pancasila dan Undang-Undang Dasar Negara Republik Indonesia Tahun 1945.

Menurut Jimly Asshiddiqie bahwa "Komisi Pemilihan Umum adalah lembaga negara yang menyelenggarakan pemilihan umum di Indonesia, yakni meliputi Pemilihan Umum Anggota DPR/DPD/DPRD, Pemilihan Umum Presiden dan Wakil Presiden, serta Pemilihan Umum Kepala Daerah dan Wakil Kepala Daerah. Komisi Pemilihan Umum tidak dapat disejajarkan kedudukannya dengan lembaga-lembaga negara yang lain yang kewenangannya ditentukan dan diberikan oleh UUD 1945. Bahkan nama Komisi Pemilihan Umum belum disebut secara pasti atau tidak ditentukan dalam UUD 1945, tetapi kewenangannya sebagai penyelenggara pemilihan umum sudah ditegaskan dalam Pasal 22E ayat (5) UUD 1945 yaitu Pemilihan umum diselenggarakan oleh suatu komisi pemilihan umum yang bersifat nasional, tetap, dan mandiri. Artinya, bahwa Komisi Pemilihan Umum itu adalah penyelenggara pemilu, dan sebagai penyelenggara bersifat nasional, tetap dan mandiri (independen)” (Asshiddiqie Jimly, 2006 : 236-239). 


\section{Komisi Pemberantasan korupsi}

Salah satu lembaga negara penunjang yang dibentuk pada era reformasi di Indonesia adalah Komisi Pemberantasan Korupsi (KPK). Lembaga ini dibentuk sebagai salah satu bagian agenda pemberantasan korupsi yang merupakan salah satu agenda terpenting dalam pembenahan tata pemerintahan di Indonesia. KPK berdiri pada tahun 2002 dan didirikan oleh Presiden Megawati Soekarnoputri. Adapun pembentukan KPK ini didasari karena Presiden RI pada waktu itu melihat institusi kepolisian dan kejaksaan dinilai terlalu kotor, karenanya untuk menangkap para koruptor dirasa tidak sanggup. Selain itu, polisi dan jaksa sulit untuk dibubarkan sehingga terbentuklah KPK. Gagasan awal berdirinya KPK sendiri sudah muncul sejak era pemerintahan BJ Habibie yang telah mengeluarkan peraturan UndangUndang No.28 pada tahun 1999 mengenai Penyelenggaraan Negara yang bebas dan bersih dari KKN. BJ Habibie selanjutnya mulai membentuk berbagai badan/komisi baru seperti KPPU/ Lembaga Ombudsman, dan KPKPN.

Komisi Pemberantasan Korupsi, atau disingkat menjadi KPK, adalah komisi di Indonesia yang dibentuk pada tahun 2003 untuk mengatasi, menanggulangi dan memberantas korupsi di Indonesia. Komisi ini didirikan berdasarkan kepada Undang-Undang Republik Indonesia Nomor 30 Tahun 2002 mengenai Komisi Pemberantasan Tindak Pidana Korupsi. Salah satu hasil dari Perubahan Undang-undang Dasar Negara Republik Indonesia Tahun 1945 (UUD Negara RI Tahun 1945) adalah beralihnya supremasi Majelis Permusyawaratan Rakyat (MPR) menjadi supremasi konstitusi. Akibatnya, MPR bukan lagi lembaga tertinggi negara karena semua lembaga negara didudukkan sederajat dalam mekanisme checks and balances. Sementara itu, konstitusi diposisikan sebagai hukum tertinggi yang mengatur dan membatasi kekuasaan lembaga-lembaga negara.

Komisi Pemberantasan Korupsi Republik Indonesia ialah sebuah Lembaga negara yang bertujuan untuk meningkatkan hasil guna dan daya guna terhadap sebuah upaya pemberantasan korupsi. Lembaga ini tidak terpengaruh oleh kekuasaan manapun untuk menjalankan tugas dan kewajibannya sehingga bersifat independen. Dalam melaksanakan tugasnya, Lembaga ini berpedoman pada 5 asas, yang mencakup keterbukaan, kepentingan umum, proporsionalitas, akuntabilitas, dan kepastian hukum.

Pimpinan komisi pemberantasan korupsi terdiri dari lima orang yang merangkap sebagai anggota yang terdiri dari unsur pemerintah dan unsur masyarakat, sehingga pada sistem pengawasan yang dilakukan oleh masyarakat terhadap kinerja komisi pemberantasan korupsi dalam melakukan penyelidikan, penyidikan serta penuntutan terhadap pelaku tindak pidana korupsi tetap melekat pada komisi pemberantasan korupsi. Di dalam Undang-Undang No 19 Tahun 2019 mengatakan bahwa pengertian dari Komisi Pemberantasan Tindak Pidana Korupsi yang selanjutnya disebut Komisi Pemberantasan Korupsi adalah lembaga negara dalam rumpun kekuasaan eksekutif yang melaksanakan tugas pencegahan dan pemberantasan Tindak Pidana Korupsi sesuai dengan UndangUndang ini. Dan merupakan lembaga negara dalam rumpun kekuasaan eksekutif yang dalam melaksanakan tugas dan wewenangnya bersifat independen dan bebas dari pengaruh kekuasaan manapun. 
Upaya melepas budaya korupsi yang telah mengakar di Partai Politik yang ada di Republik Indonesia.

Korupsi telah sejak lama terjadi di Indonesia. Praktik-praktik seperti penyalahgunaan wewenang, penyuapan, pemberian uang pelicin, pungutan liar, pemberian imbalan atas dasar kolusi dan nepotisme serta penggunaan uang negara untuk kepentingan pribadi, oleh masyarakat diartikan sebagai suatu perbuatan korupsi dan dianggap sebagai hal yang lazim terjadi di negara ini. Ironisnya, walaupun usaha-usaha pemberantasannya sudah dilakukan lebih dari empat dekade, praktik-praktik korupsi tersebut tetap berlangsung, bahkan ada kecenderungan modus operandinya lebih canggih dan terorganisir, sehingga makin mempersulit penanggulangannya.

Pemberantasan korupsi tidak cukup dilakukan hanya dengan komitmen semata karena pencegahan dan penanggulangan korupsi bukan suatu pekerjaan yang mudah. Komitmen tersebut harus diaktualisasikan dalam bentuk strategi yang komprehensif untuk meminimalkan keempat aspek penyebab korupsi yang telah dikemukakan sebelumnya. Strategi tersebut mencakup aspek preventif, detektif dan represif, yang dilaksanakan secara intensif dan terus menerus. Ketiga aspek tersebut yaitu :

1. Strategi preventif diarahkan untuk mencegah terjadinya korupsi dengan cara menghilangkan atau meminimalkan faktor-faktor penyebab atau peluang terjadinya korupsi. Strategi preventif dapat dilakukan dengan:
a. Memperkuat
Dewan
Perwakilan Rakyat;
b. Memperkuat Mahkamah Agung dan jajaran peradilan di bawahnya
c. Membangun kode etik di sektor publik

d. Membangun kode etik di sektor Parpol, Organisasi Profesi dan Asosiasi Bisnis. Meneliti sebab-sebab perbuatan korupsi secara berkelanjutan.

e. Penyempurnaan manajemen sumber daya manusia (SDM) dan peningkatan kesejahteraan Pegawai Negeri

f. Pengharusan pembuatan perencanaan stratejik dan laporan akuntabilitas kinerja bagi instansi pemerintah

g. Peningkatan kualitas penerapan sistem pengendalian manajemen; Penyempurnaan manajemen Barang Kekayaan Milik Negara (BKMN)

h. Peningkatan kualitas pelayanan kepada masyarakat

i. Kampanye untuk menciptakan nilai (value) anti korupsi secara nasiona

2. Strategi Detektif Strategi detektif diarahkan untuk mengidentifikasi terjadinya perbuatan korupsi. Strategi detektif dapat dilakukan dengan :

a. Perbaikan sistem dan tindak lanjut atas pengaduan dari masyarakat

b. Pemberlakuan kewajiban pelaporan transaksi keuangan tertentu

c. Pelaporan kekayaan pribadi pemegang jabatan dan fungsi public

d. Partisipasi Indonesia pada gerakan anti korupsi dan anti pencucian uang di masyarakat internasional

e. Dimulainya penggunaan nomor kependudukan nasional 
f. Peningkatan kemampuan APFP/SPI dalam mendeteksi tindak pidana korupsi.

3. Strategi represif diarahkan untuk menangani atau memproses perbuatan korupsi sesuai dengan peraturan perundang-undangan yang berlaku. Strategi represif dapat dilakukan dengan :

a. Pembentukan Badan/Komisi Anti Korupsi

b. Penyidikan, penuntutan, peradilan, dan penghukuman koruptor besar (Catch some big fishes)

c. Penentuan jenis-jenis atau kelompok-kelompok korupsi yang diprioritaskan untuk diberantas

d. Pemberlakuan konsep pembuktian terbalik

e. Meneliti dan mengevaluasi proses penanganan perkara korupsi dalam sistem peradilan pidana secara terus menerus

f. Pemberlakuan sistem pemantauan proses penanganan tindak pidana korupsi secara terpadu

g. Publikasi kasus-kasus tindak pidana korupsi beserta analisisnya

h. Pengaturan kembali hubungan dan standar kerja antara tugas penyidik tindak pidana korupsi dengan penyidik umum, PPNS dan penuntut umum

Akibat hukum terhadap tindak pidana korupsi yang dilakukan oleh pihak Komesioner dan pihak mantan caleg PDIP

Tugas Partai politik tidak hanya bertugas sebagai merebut kursi dan mengumpulkan suara pada saat pemilihan umum, tetapi partai politik juga berfungsi sebagai solusi untuk kepentingan bersama. Fungsi dari Partai Politik diantaranya berfungsi sebagai sarana pendidikan politik bagi anggota dan masyarakat luas agar menjadi warganegara Indonesia yang sadar akan hak dan kewajibannya dalam kehidupan bermasyarakat, berbangsa, dan bernegara, penciptaan iklim yang kondusif bagi persatuan dan kesatuan bangsa Indonesia untuk kesejahteraan masyarakat penyerap, penghimpun, dan penyalur aspirasi politik masyarakat dalam merumuskan dan menetapkan kebijakan negara, partisipasi politik warga negara Indonesia, rekrutmen politik dalam proses pengisian jabatan politik melalui mekanisme demokrasi dengan memperhatikan kesetaraan dan keadilan gender.

Dari kasus yang ada harusnya pihak Masiku dalam mengikutinya melalui mekanisme demokrasi. Tidak melalui suap kepada pihak komisioner KPU walaupun awal mula siapa yang mempunyai inisiatif untuk melakukan tindakan penyuapan. Baik dimulai dari pihak komisioner maupun pihak Masiku. Disini jelas adanya faktor pendorong untuk melakukan tindakan korupsi. Yang seharusnya tidak boleh dilakukan. Faktor-faktor yang mendorong untuk melakukan tindakan penyuapan diantara faktor kekuasaan, keserakahan, kesempatan kebutuhan serta kecurangan, terpenuhi semua sebagaimana dijelaskan dalam teori faktor terjadinya tindak pidana korupsi. Untuk menjadi anggota KPU maka bersumpah lebih dahulu di mana bunyi dari pada sumpah tersebut adalah "Demi Allah (Tuhan) , saya bersumpah/berjanji: Bahwa saya akan memenuhi tugas dan kewajiban saya sebagai anggota komisi pemilihan umum. Komisi pemilihan umum Provinsi/Komisi pemilihan umum Kabupaten/Kota dengan sebaik-baiknya sesuai dengan peraturan perundang dengan berpedoman pada pancasila dan 
Undang-Undang Dasar Negara Republik Indonesia Tahun 1945.

Seorang Komisioner seharusnya tidak melakukan tindak pidana korupsi karena sudah disumpah dengan mengatakan akan memenuhi tugas dan kewajiban dengan sebaik-baiknya sesuai dengan peraturan perundang dengan berpedoman pada pancasila dan UndangUndang Dasar Negara Republik Indonesia Tahun 1945. Tetapi apa yang kita lihat di media sosial diberitakan bahwa seorang komisioner KPU Wahyu Setiap telah menerima suap dari seorang mantan caleg dari PDIP Masiku. Disini jelas ternyata baik anggota komisioner maupun mantan Caleg dari PDIP mempunyai moral yang rendah. Mereka tidak bisa mengaplikasikan aturan-aturan yang ada. Oleh karena itu untuk membuat yang bersangkutan jera dan tidak mengulangi lagi perlu hukuman yang berat dan tegas. Lembaga hukum harus menghukum secara objektif tanpa pandang bulu, kalau negara kita tidak mau dianggap sebagai negara terkorup atau negara budaya korupsi. Baik yang menerima suap maupun yang memberi suap. Sebagai peringatan bagi yang lain.

Menurut Undang-Undang No 20 Tahun 2001 Tentang Pemberantasan Tindak Pidana Korupsi Pasal 5 ayat (1) mengatakan bahwa dipidana dengan pidana penjara paling singkat 1 (satu) tahun dan paling lama 5 (lima) tahun dan atau pidana denda paling sedikit $\mathrm{Rp}$ 50.000.000,00 (lima puluh juta rupiah) dan paling banyak Rp 250.000.000,00 (dua ratus lima puluh juta rupiah) setiap orang yang memberi atau menjanjikan sesuatu kepada pegawai negeri atau penyelenggara negara dengan maksud supaya pegawai negeri atau penyelenggara negara tersebut berbuat atau tidak berbuat sesuatu dalam jabatannya, yang bertentangan dengan kewajibannya atau memberi sesuatu kepada pegawai negeri atau penyelenggara negara karena atau berhubungan dengan sesuatu yang bertentangan dengan kewajiban, dilakukan atau tidak dilakukan dalam jabatannya.

Pasal 12 huruf (e) mengatakan bahwa dipidana dengan pidana penjara seumur hidup atau pidana penjara paling singkat 4 (empat) tahun dan paling lama 20 (dua puluh) tahun dan pidana denda paling sedikit Rp 200.000.000,00 (dua ratus juta rupiah) dan paling banyak $\mathrm{Rp}$ 1.000.000.000,00 (satu miliar rupiah): (e). Pegawai negeri atau penyelenggara negara yang dengan maksud menguntungkan diri sendiri atau orang lain secara melawan hukum, atau dengan menyalahgunakan kekuasaannya memaksa seseorang memberikan sesuatu, membayar, atau menerima pembayaran dengan potongan, atau untuk mengerjakan sesuatu bagi dirinya sendiri.

\section{PENUTUP \\ Kesimpulan}

Berdasarkan pembahasan yang kami uraikan maka kami mempunyai kesimpulan adalah bahwa upaya melepas budaya korupsi yang telah mengakar di Partai Politik yang ada di Republik Indonesia adalah dengan strategi melalui aspek preventif, detektif dan represif, yang dilaksanakan secara intensif dan terus menerus. Selanjutnya Akibat hukum terhadap tindak pidana korupsi yang dilakukan oleh pihak Komesioner dan pihak mantan caleg PDIP adalah menerima saksi yang berat, bagi pihak anggota komisioner dipecat atau mengundurkan diri selain saksi pidana dan bagi mantan calon legislatif adalah saksi pidana.

\section{Saran}

Dengan demikian penulis beranggapan perlu adanya sosialisasi dari lembaga KPK tentang masalah korupsi serta akibat hukum melakukan tindak pidana korupsi. Selain itu seharusnya bahwa semua 
lembaga pemerintah dalam mengelola pemerintahan yang transparan dan akuntabilitas dalam hal pelaksanaan sebagai penyelenggara negara.

DAFTAR PUSTAKA

Andi Hamzah, Delik-Delik Tersebar di Luar KUHP , Pradnya Paramitha, Jakarta, 1985

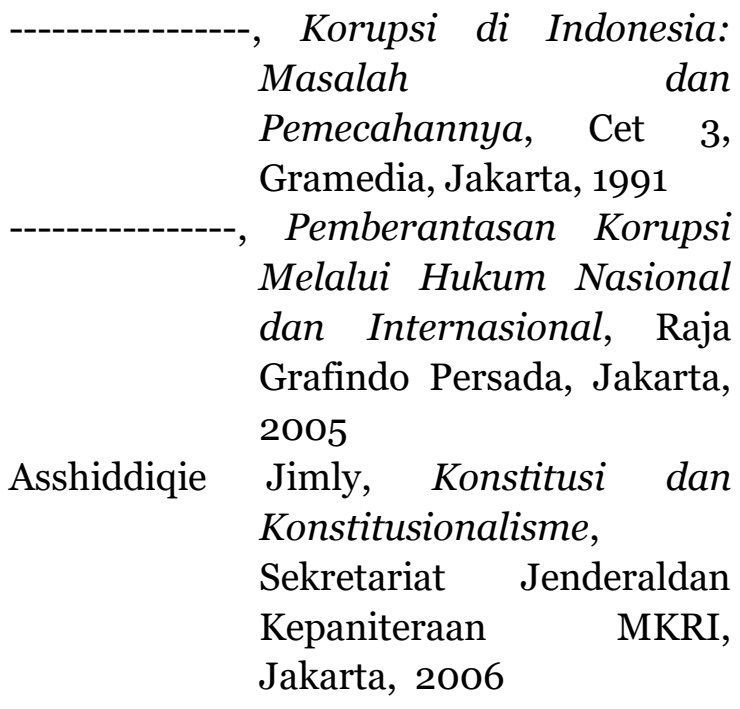

Budiardjo, Miriam, Dasar-Dasar Ilmu Politik,Gramedia Pustaka Utama,Jakarta, 2008

Ermansyah Djaja, Memberantas Korupsi Bersama KPK, Sinar Grafika, Jakarta, 2010

Mariam Budiarjo, Dasar-dasar Ilmu politik,Gramedia Pustaka, Jakarta, 2011

Morissan, Hukum Tata Negara Era Reformasi, Ramdina Prakarsa, Jakarta, 2005

Muladi, Lembaga Pidana Bersyarat, Alumni, Bandung, 2002
R. Wiyono, Pembahasan Undang-Undang Pemberantasan Tindak Pidana Korupsi, Sinar Grafika, Jakarta, 2005

Soerjono Soekanto dan Sri Mamudji, Penelitian Hukum Normatif Suatu Tinjauan Singkat, Raja Grafindo Persada, Jakarta, 2006

Surachmin, Suhandi Cahaya, Strategi dan Teknik Korupsi Mengetahui untuk Mencegah,Sinar Grafika, Jakarta, 2011

Undang-undang Dasar Negara Republik Indonesia Tahun 1945

Undang-Undang No 19 Tahun 2019 Tentang Pemberantasan Tindak Pidana Korupsi

Undang-Undang No 2 Tahun 2011 Tentang Partai Politik

Undang-Undang No 20 Tahun 2001 Tentang Pemberantasan Tindak Pidana Korupsi

Undang-Undang No 7 Tahun 2017 Tentang Pemilihan Umum

W.J.S.Poerwadarminta, Kamus Umum Bahasa Indonesia,Jakarta, Balai Pustaka, 2007 